\title{
Evidence that glutamine modulates respiratory burst in stressed rat polymorphonuclear cells through its metabolism into arginine
}

\author{
Christophe Moinard $^{1,2} *$, Florence Caldefie-Chezet ${ }^{1}$, Stephane Walrand ${ }^{1,2}$, Marie-Paule Vasson ${ }^{1}$ and \\ Luc Cynober ${ }^{2,3}$ \\ ${ }^{1}$ Laboratoire de Biochimie, Biologie Moléculaire et Nutrition EA 2416 and Centre de Recherche en Nutrition Humaine, \\ Faculté de Pharmacie, Clermont-Ferrand, France \\ ${ }^{2}$ Laboratoire de Biologie de la Nutrition, Faculté de Pharmacie, 4 avenue de l'Observatoire, 75270 Paris Cedex 06, France \\ ${ }^{3}$ Laboratoire de Biochimie, Hotel-Dieu, AP-HP and Inserm U341, France
}

(Received 29 October 2001 - Revised 10 July 2002 - Accepted 11 August 2002)

\begin{abstract}
Glutamine (GLN) and arginine (ARG) are recognized for their ability to modulate immune cell function. However, the metabolic pathways involved in their action remain unclear. It was recently shown that GLN- or ARG-enriched diets increased radical oxygen species (ROS) production by neutrophils from stressed rats. Since these two amino acids have a tied metabolism, we hypothesized that conversion between GLN and ARG (and its active metabolites NO ${ }^{\bullet}$ and polyamines) might be involved. To test this hypothesis male Sprague-Dawley rats ( $n$ 117) were randomized into thirteen groups: rats in eleven groups were rendered catabolic by dexamethasone injection $(1.5 \mathrm{mg} / \mathrm{kg}$ per d for $5 \mathrm{~d})$ and $6.8 \mathrm{mmol}$ either GLN, ARG or non-essential amino acids (NEAA; glycine, alanine and histidine)/kg per $\mathrm{d}$ were given by the enteral route; one group was pair-fed to the treated groups. The regimens of all the groups were rendered isonitrogenous by the addition of NEAA. The last group was not treated and was fed ad libitum. For each supplementation three subgroups were formed, each of which received a specific inhibitor: methionine sulfoximine (inhibitor of GLN synthase; $100 \mathrm{mg} / \mathrm{kg}$ per d), S-methylthiourea (inhibitor of inducible $\mathrm{NO}^{\bullet}$ synthase (iNOS); $50 \mathrm{mg} / \mathrm{kg}$ per d) and difluoromethylornithine (inhibitor of ornithine decarboxylase (ODC); $50 \mathrm{mg} / \mathrm{kg}$ per d). Oxidative metabolism, intracellular $\mathrm{H}_{2} \mathrm{O}_{2}$, and extracellular $\mathrm{O}_{2}{ }^{-}$- production were measured in unstimulated and phorbol myristate acetate-stimulated polymorphonuclear neutrophils. GLN- and ARG-enriched diets increased respiratory burst by neutrophils (oxidative metabolism of 152 (SEM 24) and 138 (SEM 45) v. 57 (SEM 18) $\mathrm{mV}$ for GLN-, ARG- and NEAA-enriched diets respectively, $P<0.05)$. In vivo inhibition of iNOS or ODC decreased ROS production induced by GLN and ARG. In vivo inhibition of GLN synthase did not modify the effect of ARG on ROS production. In conclusion, GLN and ARG modulate ROS production in neutrophils from stressed rats by the same pathway involving polyamine and $\mathrm{NO}^{\bullet}$ synthesis.
\end{abstract}

Glutamine: Arginine: Polymorphonuclear cells: Polyamines: Nitric oxide: Respiratory burst

Response to injury is characterized by a hypermetabolic state and an alteration of protein metabolism (Jeevanandam, 1995). In particular, injury is also associated with marked changes in the concentrations of free amino acids, especially glutamine (GLN) and arginine (ARG), both in plasma and muscles (Cynober, 1989; Ardawi \& Jamal, 1990; Ardawi \& Majzoub, 1991). One current view is that the decrease in GLN and ARG availability is partly responsible for the dysimmunity often observed in stress (Newsholme et al. 1988; Brittenden et al. 1994; Pastores et al. 1994). Under these conditions, GLN- and ARG-enriched diets may have pharmacological effects on immunity. Many studies (for a review, see De Bandt \& Cynober, 1998) have shown the ability of these two

Abbreviations: AL, ad libitum group; ARG, arginine; DEX, dexamethasone; DFMO, $\alpha$-difluoromethylornithine; GLN, glutamine; MSO, methionine sulfoximine; NEAA, non-essential amino acids; PF, pair-fed group; PMN, polymorphonuclear neutrophils; ROS, reactive oxygen species; SMT, Smethylthiourea.

* Corresponding author: Dr C. Moinard, fax + 331537397 56, email christophe.moinard@ nutrition-paris5.org 
amino acids to modulate immune functions under physiological or pathological conditions. They are known to improve T-cell immmunity (Alexander, 1995; Robinson et al. 1999), to stimulate macrophage functions (Calder \& Yaqoob, 1999; Wu et al. 2000) and polymorphonuclear neutrophil (PMN) bactericidal power (Moffat et al. 1996; Furukawa et al. 1997, 2000; Holm et al. 1999; Moinard et al. 1999). However, the mechanisms involved in these actions are still unclear. In a recent study (Moinard et al. 1999) we showed the ability of an enterally administered diet supplemented with GLN and ARG to stimulate $\mathrm{H}_{2} \mathrm{O}_{2}$ production by PMN. However, the mechanisms involved were not elucidated. We (Moinard et al. 2000) and others (Murphy \& Newsholme, 1998) have shown that GLN may be an ARG precursor for $\mathrm{NO}^{\bullet}$ synthesis in immune cells. These data suggest that these two amino acids have a tied metabolism and so their immunomodulatory effects may be related to a common pathway. We hypothesized that GLN may act via ARG or that ARG may act through GLN neosynthesis.

The aim of the present study was therefore to determine the metabolic pathways involved in GLN and ARG action on radical oxygen species (ROS) production by PMN from stressed rats. The catabolic state was obtained by daily intraperitoneal injection of glucocorticoids (i.e. dexamethasone; DEX). This model has been demonstrated to lead to a highly reproducible catabolic state in rats, including anorexia, protein breakdown and negative $\mathrm{N}$ balance (Odedra et al. 1983; Ardawi \& Jamal, 1990; Parry-Billings et al. 1990; Minet-Quinard et al. 2000). In addition, glucocorticoids have immunosuppressive effects; they are responsible for changes in the distribution of leucocytes observed during stress (Shijo et al. 1998). These changes may have a significant impact on the functioning and effectiveness of the immune response (Shijo et al. 1998).

We evaluated the enhancing effect of GLN and ARG on respiratory burst using three different methods (chemiluminescence, flow cytometry and ferricytochrome reduction) in glucocorticoid-treated rats. We also used metabolic inhibitors in GLN- and ARG-supplemented stressed rats in order to block different metabolic pathways at the whole body level (Fig. 1): methionine sulfoximine (MSO), a specific inhibitor of GLN synthase (Heeneman \& Deutz, 1993), to determine whether ARG acts through neosynthesis of GLN; S-methylthiourea (SMT), a specific inhibitor of inducible $\mathrm{NO}^{\bullet}$ synthase (Ruetten \& Thiemermann, 1996), to determine whether GLN and ARG act by a process dependent on $\mathrm{NO}^{\bullet}$ synthesis (the active metabolite of ARG); $\alpha$-difluoromethylornithine (DFMO), a specific inhibitor of ornithine decarboxylase (Nsi-Emvo et al. 1996) to determine whether GLN and ARG act via polyamine synthesis (deriving from ARG).

\section{Materials and methods}

\section{Chemicals}

All chemicals were purchased from Sigma (St-QuentinFallavier, France) except for $2^{\prime}-7^{\prime}$-dichlorofluorescin diacetate (DCFH-DA; Acros, Noisy-le-Grand, France), Plasmagel $^{\circledR}$ (Belon, Neuilly-sur-Seine, France), and DEX (Soludecadron ${ }^{\circledR}$; Merck Sharp \& Dohm, Riom, France).

\section{Animals and study design}

A total of 117 male Sprague-Dawley rats (3 months old) were used (Iffa Credo, L'Arbresle, France). After their arrival at our animal facility the rats were maintained on a standard chow diet (A04: $170 \mathrm{~g}$ proteins, $30 \mathrm{~g}$ fat, $590 \mathrm{~g}$ carbohydrates, and $210 \mathrm{~g}$ water/kg, fibre, vitamins and minerals; Usine d'Alimentation Rationnelle, Villemoisson-surOrge, France) and received water ad libitum. They were

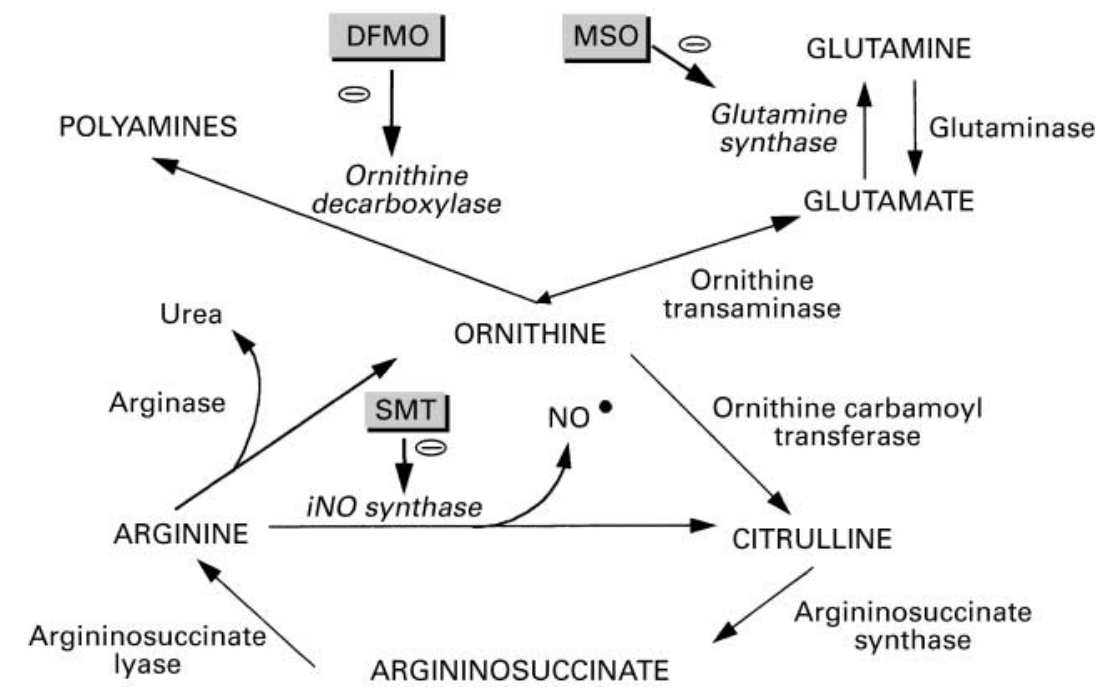

Fig. 1. Metabolic pathways involved in glutamine and arginine action on radical oxygen species produced by polymorphonuclear cells in stressed rats. Metabolic pathways were blocked (-) by metabolic inhibitors $\alpha$-difluoromethylornithine (DFMO), methionine sulfoximine (MSO) and S-methylthiourea (SMT). iNO synthase =inducible $\mathrm{NO}^{\bullet}$ synthase. 
kept in individual cages in a controlled environment (constant temperature of $24^{\circ} \mathrm{C}$ ) and light cycle (lights off 8.00-20.00 hours, lights on 20.00-8.00 hours). After this acclimatization period, the rats were randomized into thirteen groups (nine per group) as shown in Table 1.

For the next $5 \mathrm{~d}$ (day 0 to day 4 ) all the rats (except those that were pair-fed) had free access to the chow diet as described above. DEX-treated groups (i.e. groups 3 to 13, see Table 1) received a daily intraperitoneal injection of DEX $(1.5 \mathrm{mg} / \mathrm{kg}$ per d) for $5 \mathrm{~d}$ (day 0 to day 4 ) as previously described (Minet-Quinard et al. 2000). The pairfed group (PF) was pair-fed to DEX groups and received a daily isovolumic intraperitoneal injection of $\mathrm{NaCl}(9 \mathrm{~g} / \mathrm{l})$. The rationale for the study of a $\mathrm{PF}$ was the fact that DEX induces anorexia (Minet-Quinard et al. 2000); studying a PF thus isolates the effect of the treatment itself from the effects induced by marked anorexia. In addition to their oral chow diet the supplemented groups received enteral supplementation of GLN or ARG $(6.8 \mathrm{mmol} / \mathrm{kg}$ per d) (day 0 to day 4) by oral administration as described previously (Lasnier et al. 1996). The dose of $6.8 \mathrm{mmol} / \mathrm{kg}$ per d corresponds to $1.00 \mathrm{~g}$ GLN/ $\mathrm{kg}$ per $\mathrm{d}$ and $2.19 \mathrm{~g}$ $\mathrm{ARG} / \mathrm{kg}$ per $\mathrm{d}$. These doses are in the range of those used in the literature (Barbul, 1995; Fürst \& Stehle, 1995; Farges et al. 1999; Moinard et al. 1999) and are an extrapolation of dosages used in human subjects allowing for the high metabolic rate of rats (Cynober, 1989). The enteral route was chosen to provide supplements, rather than mixing them with chow (Le Bricon et al. 1995), to be certain that rats suffering from anorexia received the targeted amount of pharmaconutrients. The enteral supplementation of all the groups was rendered isonitrogenous (up to $0.5 \mathrm{~g} \mathrm{~N} / \mathrm{kg}$ per d) by addition of a mixture of non-essential amino acids (NEAA; glycine, alanine, histidine in equimolar amounts). DEX-NEAA and PF groups received only the NEAA mixture $(0 \cdot 5 \mathrm{~g} \mathrm{~N} / \mathrm{kg}$ per $\mathrm{d})$ as a supplement to their regimen. In our experimental conditions, the NEAA mixture exerted neither pharmacological nor adverse effects on metabolic pathways (MinetQuinard et al. 1999). MSO-, SMT- and DFMO-treated groups received MSO $(100 \mathrm{mg} / \mathrm{kg}$ per d), SMT $(50 \mathrm{mg} / \mathrm{kg}$ per d) and DFMO (50 $\mathrm{mg} / \mathrm{kg}$ per d) respectively by the enteral route for $6 \mathrm{~d}$ (day -1 to day 4 ). The use of NEAA groups allowed us to determine whether the metabolic inhibitors are able to modify per se the parameters measured. We did not determine the effect of MSO in the GLN-supplemented group since GLN synthase is not involved in GLN catabolism. Dosages of inhibitors were selected on the basis of literature values (Nsi-Emvo et al. 1996; Ruetten \& Thiemermann, 1996; Minet et al. 1997). Concerning the effect of inhibitors per se, GLN synthase activity in muscle (extensor digitorum longus) was determined using a colorimetric assay (Minet et al. 1997) and we previously demonstrated that GLN synthase activity was not detectable in muscles from MSO-treated rats (Moinard et al. 2002). In our experimental conditions, SMT abolished $\mathrm{NO}^{\bullet}$ secretion in stimulated macrophages (Moinard et al. 2000), which assess that SMT block NO synthase in vivo. In the case of DFMO, ornithine decarboxylase was not measured since this enzyme has a very short half-life and $24 \mathrm{~h}$ had elapsed since the last injection. However, it is well known that DFMO blocks ornithine decarboxylase activity in our experimental conditions (Messina et al. 1992; Morgan, 1994; Raul et al. 1995; Walters et al. 1998).

The ad libitum group (AL) received no treatment, and was fed ad libitum.

Animal care and experimentation complied with the rules of our institution, and two of us (L.C. and M.-P.V.) are authorized by the French Ministry of Agriculture and Forestry to use this type of experimental model.

After $24 \mathrm{~h}$ following the last injection, rats in the

Table 1. Treatment and nutritional supplementation of the thirteen groups studied

\begin{tabular}{|c|c|c|c|c|c|c|c|}
\hline \multirow[b]{2}{*}{ Groups } & \multirow[b]{2}{*}{ Injection } & \multicolumn{3}{|c|}{$\begin{array}{c}\text { Amino acid } \\
\text { Supplementation } \\
(6.8 \mathrm{mmol} / \mathrm{kg} \text { per } \mathrm{d} \text { and } \\
\text { up to } 0.5 \mathrm{~g} \mathrm{~N} / \mathrm{kg} \text { per } \mathrm{d} \\
\text { by addition of NEAA) }\end{array}$} & \multicolumn{3}{|c|}{ Metabolic inhibitors } \\
\hline & & NEAA & GLN & ARG & MSO (100 mg/kg per d) & SMT (50 mg/kg per d) & DFMO $(50 \mathrm{mg} / \mathrm{kg}$ per d) \\
\hline 1. Ad libitum (AL) & None & & & & & & \\
\hline 2. Pair-fed (PF) & $\mathrm{NaCl}$ & * & & & & & \\
\hline 3. DEX-NEAA & DEX & * & & & & & \\
\hline 4. DEX- GLN & DEX & & * & & & & \\
\hline 5. DEX-ARG & DEX & & & * & & & \\
\hline 6. DEX-NEAA-MSO & DEX & * & & & $\dagger$ & & \\
\hline 7. DEX-NEAA-SMT & DEX & * & & & & $\dagger$ & \\
\hline 8. DEX-NEAA-DFMO & DEX & * & & & & & $\dagger$ \\
\hline 9. DEX-GLN-SMT & DEX & & * & & & $\dagger$ & \\
\hline 10. DEX-GLN-DFMO & DEX & & * & & & & $\dagger$ \\
\hline 11. DEX-ARG-MSO & DEX & & & * & $\dagger$ & & \\
\hline 12. DEX-ARG-SMT & DEX & & & * & & $\dagger$ & \\
\hline 13. DEX-ARG-DFMO & DEX & & & * & & & $\dagger$ \\
\hline
\end{tabular}

NEAA, non-essential amino acids; GLN, glutamine; ARG, arginine; MSO, methionine sulfoximine; SMT, S-methylthiourea; DFMO, $\alpha$-difluoromethylornithine; NaCl, intraperitoneal injection of $\mathrm{NaCl}(9 \mathrm{~g} / \mathrm{l})$ during $5 \mathrm{~d}$; DEX, intraperitoneal injection of dexamethasone $(1.5 \mathrm{mg} / \mathrm{kg}$ per d) during $5 \mathrm{~d}$.

* Amino acids were administered by the enteral route (from day 0 to day 4 ). All diets were made isonitrogenous (up to $0.5 \mathrm{gN} / \mathrm{kg}$ per d) by addition of a mixture of non-essential amino acids (glycine, histidine and alanine in equimolar amounts).

† Metabolic inhibitor was administered by the enteral route (day -1 to day 4 ). 
post-absorptive state were anaesthetized and killed by decapitation.

\section{Blood sampling}

Blood was collected on calcium heparin to isolate PMN on a gradient of Ficoll-Hypaque (for determination of oxidative metabolism and superoxide anion generation) or by sedimentation (for $\mathrm{H}_{2} \mathrm{O}_{2}$ determination).

\section{Procedures and analytical methods}

Separation of polymorphonuclear cells for determination of superoxide anion generation. Blood was layered carefully on a double gradient of Ficoll-Hypaque (Histopaque 1083 and 1119; St Quentin Fallavier, France) with equal volumes. After centrifuging $\left(700 \mathrm{~g}, 30 \mathrm{~min},+20^{\circ} \mathrm{C}\right)$, the Ficoll-Hypaque layers were removed and the PMN were transferred to a polypropylene tube (Falcon; Elvetec, Clermont Ferrand, France). The residual erythrocytes were destroyed by a short treatment with an ammonium chloride solution (ammonium chloride $16 \mathrm{~mm}$, sodium hydrogen carbonate $1 \mathrm{~mm}$, EDTA $0.01 \mathrm{~mm}$ ).

The PMN were then washed twice with PBS, resuspended and adjusted to $10^{6}$ cells/ml with Hank's balanced salt solution. Cell viability was determined by trypan blue exclusion and was more than $95 \%$. May-Grunwald-Giemsa staining of leucocytes was carried out to determine the efficiency of our separation, and gave more than $80 \%$ PMN in each preparation.

Determination of oxidative metabolism by chemiluminescence assay. Oxidative metabolism was measured by chemiluminescence. Luminol-dependent chemiluminescence was measured using a luminometer (Model 1250; LKB Pharmacia, Trappes, France) with disposable polypropylene tubes at $37^{\circ} \mathrm{C}$. PMN $\left(5 \times 10^{5}\right.$ cells $)$ were preincubated for $5 \mathrm{~min}$ at $37^{\circ} \mathrm{C}$. Luminol was then added to the medium at a final concentration of $10^{-9} \mathrm{M}$. Time was recorded from the addition of the stimulating agent (phorbol myristate acetate, $10^{-6} \mathrm{M}$ ). All the results are expressed as the maximum peak values $(\mathrm{mV})$ corresponding to the maximal activation state.

Determination of extracellular superoxide generation by ferricytochrome $C$ reduction. Extracellular $\mathrm{O}_{2}{ }^{\bullet-}$ generation was measured by reduction of ferricytochrome $\mathrm{C}$ (horse-heart type III) as previously described (Vasson et al. 1994). Briefly, PMN $\left(5 \times 10^{5}\right.$ cells $)$ pre-incubated for $5 \mathrm{~min}$ were added to a ferricytochrome C ( $0.4 \mathrm{nM})$ solution and stimulated with phorbol myristate acetate $\left(10^{-6} \mathrm{M}\right)$ for $10 \mathrm{~min}$ at $37^{\circ} \mathrm{C}$. The final volume of the reaction mixture was adjusted to $0.5 \mathrm{ml}$ with PBS. Incubation was stopped by placing the tubes in an ice bath for $10 \mathrm{~min}$. After centrifuging $\left(400 \mathrm{~g}, 10 \mathrm{~min}, 4^{\circ} \mathrm{C}\right)$, the absorbance of the supernatant fractions was measured at $545 \mathrm{~nm}$ (DU540 spectrophotometer; Beckman-Coulter, Gagny, France). The amounts of extracellular $\mathrm{O}_{2}{ }^{\bullet-}$ produced were calculated from the absorbance using an extinction coefficient of $20 \mathrm{~nm} / \mathrm{cm}$. The results are expressed in picomoles of released $\mathrm{O}_{2}{ }^{\bullet-} / \mathrm{min}$ per $10^{6}$ cells.

Measurement of intracellular hydrogen peroxide production by polymorphonuclear cells. Leucocytes were isolated and intracellular $\mathrm{H}_{2} \mathrm{O}_{2}$ was measured as previously described (Moinard et al. 1999). In brief, leucocytes were isolated after gravity sedimentation. During leucocyte oxidative burst non-fluorescent intracellular dichlorofluorescin is oxidized by $\mathrm{H}_{2} \mathrm{O}_{2}$ to highly fluorescent $2^{\prime}-7^{\prime}$-dichlorofluorescein. PMN were discerned among leucocyte populations and $2^{\prime}-7^{\prime}$-dichlorofluorescein fluorescence of PMN was measured using a flow cytometer (Epics, Coulter, USA). PMN were selected on the basis of their size and granularity by the combination of low-angle forward scattered and right-angle scattered laser light. For each determination, 2500 PMN were counted.

Results are expressed as the ratio of fluorescence produced by phorbol myristate acetate-stimulated leucocytes to fluorescence produced by non-stimulated cells.

\section{Statistical analysis}

Data are expressed as mean values and SEM. Comparisons between sets of data were made using the Kruskal-Wallis $\mathrm{H}$ test followed by the Newman-Keuls test when appropriate as indicated in Table and Fig. legends. Programme Conversationnel de Statistiques pour les sciences et le Marketing (PCSM) software was used (Deltasoft, Grenoble, France). Values of $P<0.05$ were considered significant.

\section{Results}

Effect of arginine and glutamine on oxidative metabolism in stimulated polymorphonuclear cells

Oxidative metabolism evaluated by chemiluminescence was increased under GLN and ARG supplementation

Table 2. Oxidative metabolism, extracellular $\mathrm{O}_{2}{ }^{--}$and intracellular $\mathrm{H}_{2} \mathrm{O}_{2}$ production by phorbol myristate acetate-stimulated polymorphonuclear cells (PMN) from rats fed ad libitum (AL), pair-fed (PF) or treated with dexamethasone (DEX) $(1.5 \mathrm{mg} / \mathrm{kg}$ per d during $5 \mathrm{~d}$ ) and supplemented with non-essential amino acids (NEAA; DEXNEAA), glutamine (GLN; DEX-GLN) or arginine (ARG; DEX-ARG)§ (Mean values and standard errors of the mean for nine rats per group)

\begin{tabular}{|c|c|c|c|c|c|c|}
\hline & \multicolumn{2}{|c|}{$\begin{array}{l}\text { Oxidative } \\
\text { metabolism } \\
\left(\mathrm{mV} / 5 \cdot 10^{5}\right. \\
\text { cells })\end{array}$} & \multicolumn{2}{|c|}{$\begin{array}{c}\text { Extracellular } \\
\mathrm{O}_{2}^{\bullet-}\left(\mathrm{pmol} / 10^{6}\right. \\
\text { PMN per min })\end{array}$} & \multicolumn{2}{|c|}{$\begin{array}{c}\text { Intracellular } \\
\mathrm{H}_{2} \mathrm{O}_{2} \text { (arbitrary } \\
\text { units) }\end{array}$} \\
\hline & Mean & SEM & Mean & SEM & Mean & SEM \\
\hline$A L$ & 51 & 14 & 0.86 & 0.16 & $3 \cdot 8$ & 0.6 \\
\hline PF & 6 & 2 & 0.39 & 0.08 & $1 \cdot 6^{\star}$ & 0.2 \\
\hline DEX-NEAA & 57 & 18 & 0.56 & 0.11 & $7 \cdot 0^{*} \dagger$ & $0 . \overline{7}$ \\
\hline DEX-GLN & $152^{*} \dagger \ddagger$ & 24 & $1 \cdot 41^{\star} \dagger \ddagger$ & 0.20 & $11 \cdot 2^{*} \dagger \ddagger$ & 0.6 \\
\hline DEX-ARG & $138^{*} \dagger \ddagger$ & 45 & 0.83 & 0.35 & $9 \cdot 9^{\star} † \ddagger$ & $1 \cdot 3$ \\
\hline
\end{tabular}

* Mean value within a column was significantly different from that of the $A L$ group: $P<0.05$ (by ANOVA and Newman-Keuls test, or Kruskal-Wallis test for extracellular $\mathrm{O}_{2}{ }^{--}$).

† Mean value within a column was significantly different from that of the PF group: $P<0.05$ (by ANOVA and Newman-Keuls test, or Kruskal-Wallis test for extracellular $\mathrm{O}_{2}{ }^{-}$).

$\ddagger$ Mean value within a column was significantly different from that of the DEX-NEAA group: $P<0.05$ (by ANOVA and Newman-Keuls test or Kruskal-Wallis test for extracellular $\mathrm{O}_{2}{ }^{\bullet-}$ ).

$\S$ For details of study groups and procedures, see Table 1 and p. 690. 
Table 3. Oxidative metabolism, extracellular $\mathrm{O}_{2}{ }^{\cdot-}$ and intracellular $\mathrm{H}_{2} \mathrm{O}_{2}$ production by stimulated polymorphonuclear cells $(\mathrm{PMN})$ from dexamethasone (DEX)-treated rats $(1.5 \mathrm{mg} / \mathrm{kg}$ per d during $5 \mathrm{~d})$ and supplemented with either non-essential amino acids (NEAA; DEXNEAA), NEAA + methionine sulfoximine (MSO) (DEX-NEAA-MSO), $\mathrm{NEAA}+\mathrm{S}$-methylthiourea (SMT) (DEX-NEAA-SMT) or NEAA + $\alpha$-difluoromethylornithine (DFMO) (DEX-NEAA-DFMO)*

(Mean values and standard errors of the mean for nine rats per group)

\begin{tabular}{|c|c|c|c|c|c|c|}
\hline & $\begin{array}{r}\text { Oxid } \\
\text { metal } \\
(\mathrm{mV} / \\
\mathrm{ce}\end{array}$ & $\begin{array}{l}\text { tive } \\
\text { lism } \\
10^{5} \\
\text { ) }\end{array}$ & $\begin{array}{r}\text { Extrac } \\
\mathrm{O} \\
\text { (pm } \\
\mathrm{PM} \\
\mathrm{m}\end{array}$ & $\begin{array}{l}\text { llular } \\
10^{6} \\
\text { per } \\
\text { ) }\end{array}$ & $\begin{array}{r}\text { Intrac } \\
\mathrm{H}_{2} \\
(\mathrm{arb} \\
\mathrm{un}\end{array}$ & $\begin{array}{l}\text { llular } \\
2_{2} \\
\text { rary } \\
\text { s) }\end{array}$ \\
\hline & Mean & SEM & Mean & SEM & Mean & SEM \\
\hline DEX-NEAA & 57 & 18 & 0.56 & $0 \cdot 11$ & $7 \cdot 0$ & 0.7 \\
\hline DEX-NEAA-MSO & 69 & 23 & 0.25 & 0.0 & $5 \cdot 0$ & 0.7 \\
\hline DEX-NEAA-SMT & 42 & 6 & 0.34 & 0.09 & $6 \cdot 0$ & 0.8 \\
\hline DEX-NEAA-DFMO & 31 & 20 & 0.54 & 0.10 & $5 \cdot 0$ & 0.4 \\
\hline
\end{tabular}

${ }^{*}$ For details of study groups and procedures, see Table 1 and p. 690.

(DEX-GLN, DEX-ARG $v$. AL, PF and DEX-NEAA; $P<0.05$ ) (Table 2). $\mathrm{O}_{2}{ }^{--}$release was increased in rats supplemented with GLN (DEX-GLN $v$. DEX-NEAA; $P<0 \cdot 05) . \mathrm{H}_{2} \mathrm{O}_{2}$ production by $\mathrm{PMN}$ from DEX-treated rats was increased (DEX-NEAA $v$. AL; $P<0.05$ ). This effect was specifically due to DEX because $\mathrm{H}_{2} \mathrm{O}_{2}$ production by $\mathrm{PMN}$ from $\mathrm{PF}$ was decreased (AL v. PF; $P<0.05)$. Also, in another series of experiments, the same result was obtained in DEX rats in the absence of NEAA supplementation (data not shown). Supplementation with GLN and ARG further raised $\mathrm{H}_{2} \mathrm{O}_{2}$ production by stimulated PMN (DEX-GLN, DEX-ARG $v$. DEX-NEAA; $P<0 \cdot 05$ ).

\section{Oxidative metabolism in stimulated polymorphonuclear cells from rats receiving inhibitors}

In the control groups (DEX-NEAA) the inhibitors used had

Table 4. Oxidative metabolism, extracellular $\mathrm{O}_{2}{ }^{--}$and intracellular $\mathrm{H}_{2} \mathrm{O}_{2}$ production by stimulated polymorphonuclear cells (PMN) from dexamethasone (DEX)-treated rats $(1.5 \mathrm{mg} / \mathrm{kg}$ per $\mathrm{d}$ during $5 \mathrm{~d}$ ) and supplemented with either arginine (ARG; DEX-ARG), ARG + methionine sulfoximine (MSO) (DEX-ARG-MSO), ARG + Smethylthiourea (SMT) (DEX-ARG-SMT) or ARG $+\alpha$-difluoromethylornithine (DFMO) (DEX-ARG-DFMO)†

(Mean values and standard errors of the mean for nine rats per group)

\begin{tabular}{|c|c|c|c|c|c|c|}
\hline & \multicolumn{4}{|c|}{$\begin{array}{c}\text { Extracellular } \\
\mathrm{O}_{2}^{\bullet-} \\
\left(\mathrm{pmol} / 10^{6}\right. \\
\text { PMN per } \\
\text { min) }\end{array}$} & \multicolumn{2}{|c|}{$\begin{array}{l}\text { Intracellular } \\
\mathrm{H}_{2} \mathrm{O}_{2} \text { (arbi- } \\
\text { trary units) }\end{array}$} \\
\hline & Mean & SEM & Mean & SEM & Mean & SEI \\
\hline DEX-ARG & 139 & 44 & 0.83 & 0.35 & $9 \cdot 9$ & 1 . \\
\hline DEX-ARG-MSO & 101 & 17 & 0.30 & $0 \cdot 10$ & 7.9 & $1 \cdot$ \\
\hline DEX-ARG-SMT & $32^{*}$ & 8 & 0.21 & 0.04 & $3 \cdot 7^{*}$ & 0.5 \\
\hline DEX-ARG-DFMO & $38^{*}$ & 6 & 0.71 & 0.19 & $6 \cdot 7^{*}$ & $1 \cdot 1$ \\
\hline
\end{tabular}

* Mean value within a column was significantly different from that of the DEX-ARG group: $P<0.05$ (by ANOVA and Newman-Keuls test). †For details of study groups and procedures, see Table 1 and p. 690.
Table 5. Oxidative metabolism, extracellular $\mathrm{O}_{2}{ }^{--}$and intracellular $\mathrm{H}_{2} \mathrm{O}_{2}$ production by stimulated polymorphonuclear cells (PMN) from dexamethasone (DEX)-treated rats $(1.5 \mathrm{mg} / \mathrm{kg}$ per d during $5 \mathrm{~d})$ and supplemented with either glutamine (GLN; DEX-GLN), GLN + Smethylthiourea (SMT) (DEX-GLN-SMT) or GLN + $\alpha$-difluoromethylornithine (DFMO) (DEX-GLN-DFMO)†

(Mean values and standard errors of the mean for nine rats per group)

\begin{tabular}{|c|c|c|c|c|c|c|}
\hline & \multicolumn{2}{|c|}{$\begin{array}{c}\text { Oxidative } \\
\text { metabolism } \\
\left(\mathrm{mV} / 5 \cdot 10^{5}\right. \\
\text { cells })\end{array}$} & \multicolumn{2}{|c|}{$\begin{array}{c}\text { Extracellular } \\
\mathrm{O}_{2}^{\bullet-} \\
\left(\mathrm{pmol}^{\bullet} 10^{6}\right. \\
\text { PMN per } \\
\text { min) }\end{array}$} & \multicolumn{2}{|c|}{$\begin{array}{c}\text { Intracellular } \\
\mathrm{H}_{2} \mathrm{O}_{2} \\
\text { (arbitrary } \\
\text { units) }\end{array}$} \\
\hline & Mean & SEM & Mean & SEM & Mean & SEM \\
\hline DEX-GLN & 152 & 24 & 1.41 & 0.20 & $11 \cdot 2$ & 0.6 \\
\hline DEX-GLN-SMT & $40^{*}$ & 11 & $0.33^{*}$ & 0.11 & $3 \cdot 3^{*}$ & 0.4 \\
\hline DEX-GLN-DFMO & $40^{*}$ & 9 & $0.29^{*}$ & 0.10 & $4 \cdot 8^{*}$ & 0.6 \\
\hline
\end{tabular}

* Mean value within a column was significantly different from that of the DEX-GLN group: $P<0.05$ (by ANOVA and Newman-Keuls test, or Kruskal-Wallis test for extracellular $\mathrm{O}_{2}{ }^{\bullet-}$ ).

†For details of study groups and procedures, see Table 1 and p. 690

no effect on oxidative metabolism, extracellular $\mathrm{O}_{2}{ }^{\bullet-}$ or $\mathrm{H}_{2} \mathrm{O}_{2}$ production by stimulated PMN (Table 3 ).

In the ARG-supplemented groups, oxidative metabolism was decreased in rats treated with SMT and DFMO (DEXARG-SMT, DEX-ARG-DFMO $v$. DEX-ARG; $P<0.05)$. However, the three inhibitors did not significantly modify extracellular $\mathrm{O}_{2}{ }^{\bullet-}$ generation. Concerning intracellular $\mathrm{H}_{2} \mathrm{O}_{2}$ production by PMN, only SMT and DFMO abolished the enhancing effect of ARG (DEX-ARG-SMT, DEXARG-DFMO $v$. DEX-ARG; $P<0.05$ ) (Table 4).

In GLN-supplemented groups the use of SMT and DFMO abolished the GLN-induced increase in oxidative metabolism, extracellular $\mathrm{O}_{2}^{\bullet-}$ generation and intracellular $\mathrm{H}_{2} \mathrm{O}_{2}$ production by PMN (DEX-GLN-SMT, DEXGLN-DFMO $v$. DEX-GLN; $P<0 \cdot 05$ ) (Table 5).

\section{Discussion}

The amino acids GLN and ARG are considered immunonutrients (De Bandt \& Cynober, 1998; Calder \& Yaqoob, 1999; Wu et al. 2000). This term was introduced to describe the effects of specific nutrients on immune functions. The present study, in agreement with the literature (Moffat et al. 1996, Moinard et al. 1999; Furukawa et al. 2000), shows the ability of GLN and ARG to increase respiratory burst of PMN from stressed rats. GLN is utilized by immune cells. In particular, Pithon Curi et al. (1997) have already characterized the glutaminase activity in PMN. This glutaminase activity was higher than that reported for lymphocytes and macrophages, which confirms the importance of GLN for the functioning of these cells. These authors also reported that less than $1 \%$ GLN was totally oxidized, confirming that GLN is not only a fuel for these cells but may generate other metabolites (i.e. ARG or polyamines, which may play a key role in the cells). Concerning ARG, two pathways exist in PMN. First, the arginase pathway in which ARG is converted into urea and ornithine, which generates aliphatic polyamines 
by the action of ornithine decarboxylase. Second, ARG is the substrate for $\mathrm{NO}^{\bullet}$ synthesis; $\mathrm{NO}^{\bullet}$ is synthesized by the action of $\mathrm{NO}^{\bullet}$ synthase resulting in the formation of $\mathrm{NO}^{\bullet}$ and citrulline (Cynober et al. 1995). In the present study we determined which of these metabolic pathways were involved at the whole body level in GLN- and ARG-mediated actions. For this purpose enzymic inhibitors were used. Their utilization did not modify respiratory burst in control groups (i.e. DEX-NEAA-treated groups). This result indicates that in basal conditions the metabolic inhibitors did not affect the parameters measured and that only the modifications induced by GLN or ARG were affected by the metabolic inhibitors.

The use of MSO showed that the action of ARG is not related to GLN synthesis. However, ARG stimulates respiratory burst through $\mathrm{NO}^{\bullet}$ and polyamine pathways. Several studies have shown the ability of $\mathrm{NO}^{\bullet}$ to control NADPHdependent oxidase activity (the first enzyme involved in radical oxygen species production) (Seth et al. 1994; Catz et al. 1995; Fujii et al. 1997). However, this effect of $\mathrm{NO}^{\bullet}$ on NADPH oxidase is controversial. These differences may be explained by the results of Pieper et al. (1994), who showed a biphasic effect of $\mathrm{NO}^{\bullet}$ on NADPH-oxidase activity. For these authors this mediator has a stimulatory effect at low dose and an inhibitory effect at high dose. The effect of polyamines on ROS production was previously observed in vitro (Walters et al. 1998); treatment with DFMO produced dose-dependent inhibition of the respiratory burst in PMN. Our results confirm that in vivo ARG may be a polyamine precursor that in turn stimulates ROS production in stimulated PMN. Concerning GLN, we showed that it stimulates oxidative metabolism via $\mathrm{NO}^{\bullet}$ and polyamines generation. But how does GLN generate $\mathrm{NO}^{\bullet}$ and polyamines? Recently, several studies have investigated the relationship between GLN and NO`. O'Dowd \& Newsholme (1997) have evidenced the involvement of GLN in $\mathrm{NO}^{\circ}$ production by stimulated PMN. They showed that the PMN possess the ability to produce ARG from GLN. However, these observations were made in vitro. For the first time our study has shown the ability of GLN supplementation in vivo to be an $\mathrm{NO}^{\circ}$ precursor in neutrophils.

To the best of our knowledge there are few available data on the relationship between GLN and polyamine pathways; Kandil et al. (1995) have established that GLN stimulates ornithine decarboxylase dose- and timedependently in a porcine jejunal enterocyte cell line. These data suggest that GLN may be able to stimulate ornithine decarboxylase in neutrophils. Also, GLN could be a precursor of polyamine synthesis (see Fig. 1). This last point deserves further study.

In conclusion, we demonstrate that both ARG and GLN stimulate oxidative metabolism in stressed rats via $\mathrm{NO}^{\bullet}$ and polyamine generation. However, the present study did not allow us to determine which one of these two pathways is predominant. Further study, using labelled molecules, is required to quantify the metabolic flux at the whole-body level and in PMN. It would be useful to determine whether these observations are specific to neutrophils or may be extended to other cells and tissues. GLN and ARG have many common actions on immunity and protein metabolism. In practice, they are known to improve patient outcome, to enhance immunity and posttraumatic $\mathrm{N}$ metabolism. However, there are few data available on the mechanistic action of these nutrients in catabolic patients. Knowledge of their action would help optimize their use in clinical practice. Further studies are necessary to determine which of these two amino acids is more efficacious in catabolic patients.

\section{Acknowledgements}

This work was supported in part by funds from the Ministry of Research and Technology (EA2416). C. Moinard, S. Walrand and F. Caldefie are supported by fellowships from the Ministry of Research and Technology. We are indebted to Professor J. Chassagne (CJP, Hospital) and Dr A. Tridon (Laboratory of Immunology) for helpful collaboration.

\section{References}

Alexander JW (1995) Specific nutrients and the immune response. Nutrition 11, 229-232.

Ardawi MSM \& Jamal YS (1990) Glutamine metabolism in skeletal muscle of glucocorticoid-treated rats. Clinical Science 79, $139-147$.

Ardawi MSM \& Majzoub MF (1991) Glutamine metabolism in skeletal muscle of septic rats. Metabolism 40, 155-164.

Barbul A (1995) The use of arginine in clinical practice. In Amino Acid Metabolism and Therapy in Health and Nutritional Disease, pp. 361-372 [L Cynober, editor]. Boca Raton, FL: CRC Press.

Brittenden J, Heys SD, Ross J, Park KGM \& Eremin O (1994) Nutritional pharmacology: effects of L-arginine on host defences, response to trauma and tumour growth. Clinical Science 86, 123-132.

Calder PC \& Yaqoob P (1999) Glutamine and the immune system. Amino Acids 17, 227-241.

Catz SD, Carreras MC \& Poderoso JJ (1995) Nitric oxide synthase inhibitors decrease human polymorphonuclear leukocyte luminol-dependent chemioluminescence. Free Radical Biological Medicine 19, 741-748.

Cynober L (1989) Amino acid metabolism in thermal burns. Journal of Parenteral and Enteral Nutrition 13, 196-205.

Cynober L, Le Boucher J \& Vasson MP (1995) Arginine metabolism in mammals. Journal of Nutritional Biochemistry 6, 402-413.

De Bandt JP \& Cynober L (1998) Amino acids with anabolic properties. Current Opinion in Clinical Nutrition and Metabolic Care 1, 263-272.

Farges MC, Berard MP, Raul F, Cezard JP, Joly B, Davot P, Vasson MP \& Cynober L (1999) Oral administration of a glutamine-enriched diet before or after endotoxin challenge in aged rats has limited effects. Journal of Nutrition 129, 1799-1806.

Fujii H, Ichimori K, Hoshiai K \& Nakazawa H (1997) Nitric oxide inactivates NADPH oxidase in pig neutrophils by inhibiting its assembling process. Journal of Biological Chemistry 272, 32773-32778.

Furukawa S, Saito H, Fukatsu K, Hashiguchi Y, Inaba Y, Lin MT, Inoue T, Han I, Matsuda T \& Muto T (1997) Glutamineenhanced bacterial killing by neutrophils from postoperative patients. Nutrition 13, 863-869.

Furukawa S, Saito H, Inoue T, Matsuda T, Fukatsu K, Han I, Ikeda S \& Hidemura A (2000) Supplemental glutamine augments phagocytosis and reactive oxygen intermediate 
production by neutrophils and monocytes from postoperative patients in vitro. Nutrition 16, 323-329.

Fürst P \& Stehle P (1995) Glutamine and glutamine-containing dipeptides. In Amino Acid Metabolism and Therapy in Health and Nutritional Disease, pp. 373-383 [LA Cynober, editor]. Boca Raton, FL: CRC Press.

Heeneman S \& Deutz NEP (1993) The effect of 4 days methionine sulfoximine administration on net muscle protein breakdown. Clinical Nutrition 12, 182-190.

Holm P, Kankaanranta H, Oja SS, Knowles RG \& Moilanen E (1999) No detectable NO synthesis from L-arginine or N(G)hydroxy-L-arginine in fMLP-stimulated human blood neutrophils despite production of nitrite, nitrate, and citrulline from N(G)-hydroxy-L-arginine. Journal of Leukocyte Biology 66, 127-134.

Jeevanandam M (1995) Trauma and sepsis. In Amino Acid Metabolism and Therapy in Health and Nutritional Disease, pp. 245-255 [L Cynober, editor]. Boca Raton, FL: CRC Press.

Kandil HM, Argenzio RA, Chen W, Berschneider HM, Stiles AD, Westwick JK, Rippe RA, Brenner DA \& Rhoads JM (1995) L-glutamine and L-asparagine stimulate ODC activity and proliferation in a porcine jejunal enterocyte line. American Journal of Physiology 269, G591-G599.

Lasnier E, Coudray-Lucas C, Le Boucher J, Jardel A \& Cynober L (1996) Ornithine alpha-ketoglutarate counteracts thymus involution and glutamine depletion in endotoxemic rats. Clinical Nutrition 77, 197-200.

Le Bricon T, Cynober L, Field CJ \& Baracos VE (1995) Supplemental nutrition with ornithine $\alpha$-ketoglutarate in rats with cancer-associated cachexia: surgical treatment of the tumor improves efficacy of nutritional support. Journal of Nutrition 125, 2999-3010.

Messina L, Spampinato G, Arcidiacono A, Malaguarnera L, Pagano M, Kaminska B, Kacmarek L \& Messina A (1992) Polyamine involvement in functional activation of human macrophages. Journal of Leukocyte Biology 52, 585-587.

Minet R, Villie F, Marcollet M, Meynial-Denis D \& Cynober L (1997) Measurement of glutamine synthase activity in rat muscle by a colorimetric assay. Clinica Chimica Acta 268, $121-132$.

Minet-Quinard R, Moinard C, Villié F, Walrand S, Vasson MP, Chopineau J \& Cynober L (1999) Kinetic impairment of nitrogen and muscle glutamine metabolisms in old glucocorticoidtreated rats. American Journal of Physiology 276, E558-E564.

Minet-Quinard R, Moinard C, Walrand S, Villie F, Vasson MP, Davot P, Chopineau J \& Cynober L (2000) Induction of a catabolic state in rats by DEXamethasone: dose or time dependency? Journal of Parenteral and Enteral Nutrition 24, 30-36.

Moffat FL, Han T, Li ZM, Peck MD, Jy W, Ahn YS, Chu AJ \& Bourguignon LYW (1996) Supplemental L-arginine HCl augments bacterial phagocytosis in human polymorphonuclear leukocytes. Journal of Cell Physiology 168, 26-33.

Moinard C, Caldefie F, Walrand S, Felgines C, Vasson MP \& Cynober L (2000) Involvement of glutamine, arginine and polyamines in the action of ornithine $\alpha$-ketoglutarate on macrophage functions in stressed rats. Journal of Leukocyte Biology 67, 834-840.

Moinard C, Caldefie F, Walrand S, Tridon A, Chassagne J, Vasson MP \& Cynober L (2002) Effects of ornithine 2-oxoglutarate on neutrophils in stressed rats: evidence for the involvement of nitric oxide and polyamines. Clinical Science $\mathbf{1 0 2}$, 287-295.

Moinard C, Chauveau B, Walrand S, Felgines C, Chassagne J, Caldefie F, Cynober LA \& Vasson MP (1999) Phagocyte functions in stressed rats: modulation by glutamine, arginine and ornithine 2-oxoglutarate compared. Clinical Science 97, 59-65.

Morgan DML (1994) Difluoromethylornithine (DFMO), an inhibitor of nitrite production by macrophages? Biochemical Society Transactions 22, 389S.

Murphy C \& Newsholme P (1998) Importance of glutamine metabolism in murine macrophages and human monocytes to L-arginine biosynthesis and rates of nitrite or urea production. Clinical Science 95, 397-407.

Newsholme EA, Newsholme P, Curi R, Challoner E \& Ardawi MSM (1988) A role for muscle in the immune system and its importance in surgery, trauma, sepsis and burns. Nutrition $\mathbf{4}$, 261-268.

Nsi-Emvo E, Chaton B, Foltzer-Jourdainne C, Gosse F \& Raul F (1996) Premature expression of sucrase-isomaltase triggered by cortocoid-dependent changes in polyamine metabolism. American Journal of Physiology 270, G54-G59.

Odedra BR, Bates PC \& Millward DJ (1983) Time course effect of catabolic doses of corticosterone on protein turnover in rat skeletal muscle and liver. Biochemical Journal 214, 617-627.

O'Dowd Y \& Newsholme P (1997) Evidence for the involvement of glutamine in nitric oxide production by immunostimulated neutrophils. Biochemical Society Transactions 25, 403S.

Parry-Billings $\mathrm{M}$, Leighton $\mathrm{B}$, Dimitriadis GD, Bond $\mathrm{J}$ \& Newsholme EA (1990) Effects of physiological and pathological levels of glucocorticoids on skeletal muscle glutamine metabolism in the rat. Biochemical Pharmacology 40, 1145-1148.

Pastores SM, Kvetan V \& Katz DP (1994) Immunomodulatory effects and therapeutic potential of glutamine in the critically ill surgical patient. Nutrition 10, 385-391.

Pieper GM, Clarke GA \& Gross GJ (1994) Stimulatory and inhibitory action of nitric oxide donor agents $v$. nitrovasodilators on reactive oxygen production by isolated polymorphonuclear leukocytes. Journal of Pharmacological and Experimental Therapy 269, 451-456.

Pithon Curi TC, De Melo MP, De Azevedo RB, Zorn TMT \& Curi R (1997) Glutamine utilization by rat neutrophils: presence of a phosphate-dependent glutaminase. American Journal of Physiology 273, C1124-C1129.

Raul F, Gosse F, Galluser M, Hasselmann M \& Seiler N (1995) Functional and metabolic changes in intestine mucosa of rats after enteral administration of ornithine alpha-ketoglutarate salt. Journal of Parenteral and Enteral Nutrition 19, 145-150.

Robinson LE, Bussière FI, Le Boucher J, Farges MC, Baracos VE, Cynober LA \& Field CJ (1999) Amino acid nutrition and immune function in tumor bearing rats: a comparison of glutamine-, arginine- and ornithine $\alpha$-ketoglutarate-supplemented diets. Clinical Science 97, 657-669.

Ruetten H \& Thiemermann C (1996) Prevention of the expression of inducible nitric oxide synthase by aminoguanidine or aminoethyl-isothiourea in macrophages and in the rat. Biochemical and Biophysical Research Communications 225, 525-530.

Seth P, Kumari R, Dikshit M \& Srimal RC (1994) Modulation of rat peripheral polymorphonuclear leukocyte response by nitric oxide and arginine. Blood 84, 2741-2748.

Shijo H, Iwabuchi K, Hosoda S, Watanabe H, Nagaoka I \& Sakakibara N (1998) Evaluation of neutrophil functions after experimental abdominal surgical trauma. Inflammation Research 47, 67-74.

Vasson MP, Roch-Arveiller M, Couderc R, Baguet JC \& Raichvarg D (1994) Effects of alpha-1 acid glycoprotein on human polymorphonuclear neutrophils: influence of glycan microheterogeneity. Clinica Chimica Acta 224, 65-71.

Walters JD, Cario AC, Danne MM \& Marucha PT (1998) An inhibitor of ornithine decarboxylase antagonizes superoxide generation by primed human polymorphonuclear leukocytes. Journal of Inflammation 48, 40-46.

Wu G, Meininger CJ, Knabe DA, Bazer FW \& Rhoads JM (2000) Arginine nutrition in development, health and disease. Current Opinion in Clinical Nutrition and Metabolic Care 3, 59-66. 